\title{
A Climatological and Religious Explanation of the Conception of Suñnatā in Early Buddhism
}

\section{Kyosho Hayashima}

I. Natural and climatic elements reauired for Buddhist meditation

In Early Buddhism, the Buddha and His disciples had their religious life in remote and solitary dwelling places, where they could get the most suitable conditions for Buddhist practices and realize a typical religious lite of Early Buddhism by devoting themselves in meditation and contemplation. Even after a monk's dwelling place as mentioned above was shifted to a vihāra or ārāma (monastery), the practice of dhutangas which aimed to live in contentment with little desire, had never been neglected by monks. They highly appreciated woods, caves, open places, and so on as their ideal dwelling places for the practice of meditation. It is because from the earliest date of Buddhism, those places which were located in remote and lonesome sites were regarded as the places most suitable for monks who enjoyed the simple life in clothing, food and dwelling. It shows that in Early Buddhism it was intended to follow the traditional religious life of India which prevailed all over the country. Generally speaking, Samanas or Brāhmanas originally preferred the outdoor life to the indoor life, and they, with few exceptions, used to leave home for the homeless (anagāra) state. Then they were called "pabbajitā", which literally means "wanderers". The homeless state means, according to Buddhism, a true life of bhikkhu who abandons his mundane life, enters into a solitary dwelling place and takes the Nature for a friend.

(1) K. Hayashima : Shizen-fūdoteki-kiban-to-genshi-bukkyō (Natural and Climatic Basis of Early Buddhism), JIBS vol. VIII, no. 2, March 1960. 
A Climatological and Religious Explanation (K. Hayashima)

Accordingly, the terms suñnageha and suñnāgāra (meaning "empty hut" and " empty place" respectively) appear in some old parts of Buddhist Scriptures. These were used to express monk's dwelling places in the earliest days of Buddhism. The word suñna means empty while the suñnatā is emptiness. The word suñnatā was also used in the compound “suñnatānupassanā" (observation of emptiness, in Chinese 空觀).

Then it is quite understandable that emptiness, which is one of the essential thoughts of Buddhism, has never been produced ideologically, but has been developed in search for the Truth, which was brought forth from the climate and nature of India.

The word suñnageha or suñnāgāra is often referred to in the Scriptures of Early Buddhism as an dreadful place filled with fear and terrible(3)

ness. That is why such a monk's dwelling place was far from town and village as a whole, and was mainly exposed to the menace of wild animals, mosquitoes or poisonous snakes, where there was no any guarantee of looking after monk's safety.

In spite of this, the suñnāgāra was a pleasant place for Buddhists. The Buddha and His excellent disciples, who persuaded others to have a life of suñnāgāra, resorted to their suññāgāras and enjoyed themselves in solitary life there in order to practice the patisallāna (meditation in solitude). Therefore, some heretics of that time such as Sandaka and Nigrodha criticized Buddhist monks simply as dwellers of suññāgāra.

Monk's dwelling places mentioned in Scriptures of Early Buddhism may be arranged into the three following headings: [A] Places in mountains and woods_-arañña, vana, kānana, rukkhamūla, suñnageha, suññāgāra, assama, kuṭī (kuṭikā), koțțhaka, pabbata, naga, giri, guhā, gab-

(2) In the Nanden-daizōkyō (Jap. tr. of Pāli ti-pițaka) these are translated 空屋, 空閑處, 空舍, 空所, 靜室 and so on.
(3) S. I, pp. 106 7G
S. I. p. 219 etc.
(4) S. IV, p. 133
M. III, p. 302
cf. Mil. p. 472
(5) Therīg. 389
Ud. pp. $18 \sim 20$, p. 89
Vin. II, pp. 154 9, 183 4
D.
II, p. $86 \quad$ A.V, p. 88
$\begin{array}{ll}\text { (6) M. I, pp. } 513 \sim 24 & \text { D. III, p. } 36\end{array}$ 
bhara, leṇa, kandara, sela, silā. [B] Places on the plain—abbhokāsa (ajjhokāsa), cetiya, sosānika, sīvathika, palālapuñja, bila, tĩra. [C] Buildingsvihāra, ārāma. Among those places, the arañña (forest), rukkhamūla (root of a tree) and suññāāra (empty place) are frequently used as meaning the monk's dwelling places. Buddhaghosa explained the suñnāgāra in his work "the Visuddhimagga", which runs as follows. "To an empty place: gone to an empty, secluded space (suññam vivittokāsam gato). And here he can be said to have gone to an empty place, if he has gone to any of the remaining seven kinds of abode [pabbata, kandara, giriguhā, susāna, vanapattha, abbhokāsa, palālapuñja], excepting gone to the forest and to the root of a tree." Therefore, the suñnāgāra was meant by a solitary meditation-place for early Buddhist monks. Both the arañña and rukkhamūla had been included in the thirteen kinds of dhuta-practice and esteemed as the ideal dwelling places of monks from the earliest time of Buddhism. As well as those two places, the suñnāgāra had the same conditions. In later times, it came to mean a quiet house, rather than the natural circumstances of arañña and rukkhamūla.

Buddhist scriptures tell us the reason why a suñnāgāra was an important dwelling place for Buddhist monks, and what they practised in such a suññāgāra. For example, (1) a suññāgāra is a place where the ānāpānasatikammațthāna should be practised. (2) It is a place where the practice of pațisallāna should be performed. Revata thero was called a frequenter of solitary places (brūhetā suññāgārānam), who brightened the sāla-forest at Gosinga. (3) In a suññāgāra, monks meditate upon the three sovereignties

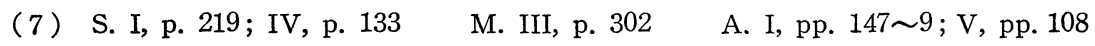
$\sim 12,324$ Vin. pp. 183 4 4 Ud. pp. 18 20 $\quad$ Vibh. p. $244 \quad$ Mil. pp. 430 $\sim 1,502 \quad$ Vis. p. 266 etc. cf. A. V, p. 122 S. II, p. 230

(8) Vis. p. 270

$\begin{array}{llll}\text { ( } 9 \text { ) S. V, pp. } 311 \sim 41 & \text { M. I, p. } 425 \text {; III, p. } 82 f f . & \text { D. II, p. } 291 & \text { A. V, }\end{array}$

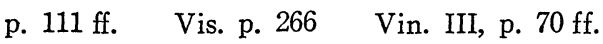

(10) M. I, pp. 212 9

(11) A. I, pp. $147 \sim 50$

(12) A. V, pp. 108 12 
A Climatological and Religious Explanation (K. Hayashima)

(atta-loka-dhamma ādhipateyya). (4) The six thoughts (anicca-anatta- ānāpānasati saññā) should be practised there. (5) The kāyagatāsati is practised there. (6) In a suñnāgāra a yogin's mind will be purified. (7) A frequenter of solitary places will attain the tenfold benefits. (8) Practices held in a suñãāgāra lead to the fulfilment of samaṇaship. (9) A frequenter of solitary places will be loved and revered by brahmacārins, since he fully practises disciplines, meditates upon the mindfullness, devotes himself to meditation and accomplishes the right observation (vipassanā).

II. The characteristics of the suñatāvihāra (dwelling in emptiness)

The purpose of Buddhist practice in a suñ̃āgāra was the attainment of non-adherence, namely, the realization of emptiness. Therefore, it may be said that a dwelling of suñnāgāra really meant "to dwell in emptiness physically and mentally".

Early Buddhism pointed out two aspects of suñnatāvihāra. These are as follows. In a process of realizing the way of emancipation, [A] a bhikkhu should have a dwelling (vihāra) in which he lives his own daily life and [B] moreover along with his mental developments, he should attain a dwelling for his mental state, from which he proceeds to a new and higher mental state successively. Then, according to Early Buddhism, bhikkhus should practise the three kinds of dwellings: the dwelling of mercy (mettāvihāra), the dwelling of earnestness, and the dwelling of dhamma-talks as the pre-requisites to bhikkhu's daily life. And with regard to the dwelling as a mental state, it is expected that bhikkhus can attain it by the practice of "the nine dwellings of gradually ascending: stages" (nava anupubbavihāra). Each of these nine dwellings was called a comfortable dwelling (phāsuvihāra) or a pleasant dwelling (sukhavihāra).
(13) Mil. p. 502
(14) ibid. p. 483
(15) M. I, pp. 33〜6
(16) Mil. p. 483
(17) A. V, pp. 131 3
(18) M. I, pp. 205 11 Cülagosingasutta
(19) ibid. Cūḷgosingasutta; M. III, pp. 25 9 Anupadasutta 
And the dwellings have a relationship that one is "gone beyond" or "uplifted" by the next one. The word samatikkamati (go beyond) and patippassambheti (up-lift) express the true meaning of suñnatāvihāara, because the word suñ̃a is in itself an endless negation. It negates not only its objects, but its own subjectivity. Thus, the suñnatāvihāra was practised by bhikkhus of Early Buddhism, because it made them dwell in their daily life as it truly is, and awakened them in the way of emancipation.

The suñnatãvihāra was also called the dwelling of great man (mahāpurisavihāra), while the mettāvihāra was regarded contemptuously as the worldly dwelling (kullavihāra). This mahāpurisavihāra, in which not only the Buddha but also His disciples dwelled many times was called the Buddhavihāra, Jinavihāra, Sarvajñatāvihāra, Mahānāgavihāra or Tathāgatavihāva in Mahāyāna Buddhism.

Next, we shall explain briefly the chracteristics of Suñnatāvihāra from its relations with the three teachings, namely, the four divine dwellings (cattāro brahmavihārā), the nine gradual dwellings of concentration (nava anupubbavihāra-samāpattiyo, or nava anupubba-nirodhā) and the the three gates of emancipation (tīṇi vimokkhā-mukhāni). These three teachings are closely connected with suñnatāvihāra and conduce to explaining the meaning of it in Early Buddhism.

(1) Suñnatāvihāra is realized in the practices of the four divine dwellings i. e. love (mettā), compassion (karun̄ā), kindliness (muditā) and equanimity (upekkhā).

(2) The nine dwellings of concentration are characterized by the application of two aspects of suñnatāvihāra. Each state of the nine dwellings

(20) Vin. II. p. 304; M. III, pp. 293 7 Piṇḍapātapārisuddhisutta

(21) Dr. S. Miyamoto: Kūshisō-oyobi-sono-hattatsu (The thought of suññatā and its development), Nihon-bukkyö-gakkai-nempö No. 17 pp. 104 5.

(22) Sn. I, 8 Vis. pp. 295 325

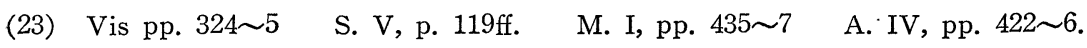
Mettāvihāra is a dwelling of dignity of purification, while the, rest of three dwellings of the cattāro brahmavihāra is called a dwelling of nothingness and emptiness. 
is understood as a dwelling of mental development of a Buddhist meditator. And such a dwelling means the dwelling of emptiness transcended by the following dwellings one by one. Accordingly, we shall have to search for the five following headings: (i) A relation between the fourfold concentration of formless existence (catasso āruppa-samāpattiyo) and the four divine dwellings; (ii) The full understanding of transiency, suffering, emptiness and non-self on the five constituents(pañca khandhā), which are observed in the nine dwellings of concentration; (iii) The essential meaning of the nine dwellings of concentration referred both to the mindfulness of emptiness and purification of emptiness; (iv) Purposes of practising the nine dwellings of concentration; (v) The formation of the nine dwellings of concentration in Early Buddhism and its background of India.

(3) A relation between the suñnatāvihãra and the three gates of emancipation may be traced in the six following headings: (i) In Early Buddhism, the three gates of emancipation consisted of suñnatānupassanā, animittānupassanā and vimokkhānupassanā (or nibbānānupassanā), without appanihitānupassanā, which was later took the place of the last one. Therefore, the formation of the three gates of emancipation dates back to nearly the time when the fourfold concentration of formless existence was established. (ii) Suñnatā and akuppā-cetovimutti (the steadfast emancipation). (iii) Suñnatā and animitta-cetosamādhi. (iv) A relation between the three gates of emancipation based upon the suñnatāvihāra and the threefold observation (tisso anupassanā). (v) A relation between the three gates of emancipation and the attainment of annih-

$\begin{array}{lll}\text { (24) } & \text { M. I, pp. } 435 \sim 7 & \text { A. IV, pp. } 422 \sim 6\end{array}$

(25) A. IV, pp. $410 \sim 8,438 \sim 48 \quad$ M. III, pp. $104 \sim 9$

(26) A. IV, p. 421 A. IV, pp. 414 8. 428 32, 437, 448, 451 6; V, pp. 7〜9, $318 \sim 21,353 \sim 8$

(27) cf. Dr. H. Nakamura: Gotama Buddha (in Jap.), pp. 66 86

(28) Therag. 92 Dhp. 93 Therīg. $45 \sim 6$

(29) S. IV, pp. 295 7

(30) S. IV, pp. 368 9 $\quad$ M. III, p. 108 
ilation (nirodha-samāpatti). (vi) Abhidhamma's explanation of the three gates of annihilation.

In short, we may say that the conception of emptiness in Early Buddhism developed in the practice of the dwelling of emptiness.

III. The developments of the theory of emptiness in Pāli Buddhism

According to the Pāli Texts, Buddha's teaching was considered to be profound in its meaning, supramandane, and in conformity with emptiness. A Pāli scripture expounds this: "Ye te suttantā Tathāgatabhāsitā gambhīra gambhīratthā lokuttarā suññatapaṭisamyuttā, te kālena kālam upasampajja viharissāmāti”." The word suñnatā-pada and the word suñnatāpațisamyutta-kathā were also used in the Scriptures with a meaning of $\underset{(35)}{\text { Buddha- }}$ dhamma that might be quite difficult for Buddhists to understand. After the death of the Buddha, the Theravādins thought that the essential meaning of Abhidhamma consisted in realizing of emptiness. The Milindapañhā tells us that our grasping of the real nature of existence, the heart (sāra) of a tree as is called in a Buddha's simile, tends to be the comprehension of emptiness. In this point, it may be said that such an understanding is very near to that of Mahāyāna Buddhism.

Originally, the conception of suñnatā derived from the comprehension of the real nature of one's self as well as of its surroundings. One of the oldest scriptures reminds us that the Buddha taught that men will be able to go beyond the fears of death when they break down their selfassertion and fully observe the world as is empty. The following two

(31) Vis. p. $629,694 \sim 5 \quad$ Pț. I, pp. $91 \sim 2$; II, p. 63

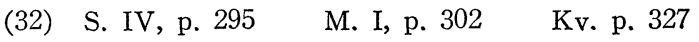

(33) Pț. I, p. $68 \quad$ Vis. pp. $699 \sim 700 \quad$ cf. Mil. pp. 333 4

(34) S. II, p. 267 ; V, pp. $406 \sim 8 \quad$ A. I, pp. $72 \sim 3$

(35) A. III, p. $107 \quad$ Vis. p. $26 \quad$ Mnd. p. $227 \quad$ Ap. p. 478, 586, 598

$\begin{array}{lllll}\text { (36) Mil, p. } 22 & \text { (37) ibid. p. } 413 \quad \text { (38) Sn. } 119 & \text { (39) S. IV, p. } 54\end{array}$

v. pp. 578 9 Cnd. pp. 246 57 (Siam. ed.) Pțs. II, pp. 177 84

Vis. p. 529, 576, 578, 653 7 Under the explanation of "suñnato lokam avekkhasu", Pțs. (II, pp. 177 84) gives the twenty six kinds of emptiness. Vis. gives also the eight ways of grasping of emptiness. 
quotations from the Pāli texts express the primitive meanings of suñnatā in Early Buddhism.

[A] "Suññato lokam avekkhassu Mogharāja sadā sato attānudițthim ūhacca, evam maccutaro siyā : evam lokam avekkhantam maccurājā na passatī' ti."

[B] “Yasmā ca kho Ānanda suñnam attena vā attaniyena vā / tasmā suñño loko ti vuccati".

Pāli Buddhism developed the theory of emptiness (suñña-kathā or suññatā-kathā) through dogmatic and analytic studies by accepting these views. Although Pāli Abhidhamma tried to establish the proper explanation of

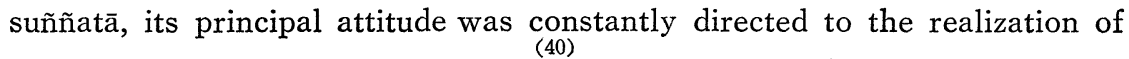
the true meaning of pratitysamutpāda. We are sure that the natural and climatic background of the conception of emptiness was already found in Pāli Buddhism. On the other hand, it may be said that Mahāyāna Buddhism failed to notice the essential meaning of suñnatāvihāra, and endeavoured to emphasize the Mahāyānistic understanding of emptiness mainly from the theoretical viewpoint of prajñāpāramitā.

In this sense, it must be remembered that the conception of emptiness is originally based upon the observation of emptiness, and it should not be limited in the field of Mahāyāna Buddhism, but should be considered as common to Buddhism in general. Therefore, our careful researches on the two Pāli scriptures, i. e. the Cūlasuññatasutta and the Mahāsuññatasutta referred to suñnatāvihāra, will give us useful instructions to improve our present understanding of emptiness.

(41) M. III, pp. 104 9 Taishō-shinshū-daizokyō vol. I, pp. 736c 8a. 小空經

(42) ibid. pp. 109 18 ibid. vol. I, pp. 738 40c. 大空經

(43) Dr. S. Miyamoto's article is very suggestive for our studying of these texts. cf. Chap. II, note (4) 